\title{
Copper nanocolloids: a new thrombus molecular imaging approach to ruptured plaque
}

\author{
Dipanjan Pan ${ }^{1 *}$, Shelton D Caruthers ${ }^{1}$, Angana SenPan ${ }^{1}$, Michael J Scott ${ }^{1}$, Anne H Schmieder ${ }^{1}$, Patrick J Gaffney ${ }^{2}$, \\ Samuel A Wickline', Gregory Lanza' \\ From 15th Annual SCMR Scientific Sessions \\ Orlando, FL, USA. 2-5 February 2012
}

\section{Summary}

Molecular imaging of fibrin offers a sensitive way to detect ruptured atherosclerotic plaque with MRI. To date we and others have heavily explored the use of gadolinium and manganese as paramagnetic metals to provide $\mathrm{T} 1$ contrast. In this project, we developed the first bivalent copper nanocolloids for MR molecular imaging of thrombus.

\section{Background}

Robust detection of fibrin expressed in the microfissues of ruptured plaque of the carotid artery offers an opportunity to intercede prophylatically in patients at high risk for stroke. Given the abundance of fibrin in microthrombus, we have focused on developing gadoliniumfree nanomedicine strategies for paramagnetic imaging of clot, respecting recent concerns regarding the pathological link between the lanthanide and Nephrogenic Systemic Fibrosis in patients with severe renal disease. The objective of this research was to develop and characterize the first molecular imaging (MI) agent for fibrin using copper-based nanocolloids (NanoQ).

\section{Methods}

Nanocolloids incorporating copper (II) complexes were synthesized (Dav=217 nm, $\zeta=-13 \mathrm{mV}$ ) and characterized for MI of thrombus. MR properties of NanoQ in suspension were defined at $3.0 \mathrm{~T}$ at $25^{\circ} \mathrm{C}$. Single slice inversion recovery and multi-echo spin echo sequences were used to calculate the ionic (per metal) and particulate (per particle) relaxivities from serial dilutions. T1weighted gradient echo imaging of fibrin clots with NanoQ or a control ( $n=3$ /group) using fibrin-specific

${ }^{1}$ Medicine, Washington University Medical School, Saint Louis, MO, USA

Full list of author information is available at the end of the article antibodies (NIB5F3) were acquired. In vivo pharmacokinetics and 24 hour biodistribution, and bioelimination of NanoQ were evaluated in rodents.

\section{Results}

The particulate relaxivity of the NanoQ was high, $\mathrm{r} 1=66,000 \pm 2200(\mathrm{~s} \bullet \mathrm{mmol}[\mathrm{NanoQ}])-1$, while the ionic r1 relaxivitiy $(4.3 \pm 0.1(\mathrm{~s} \bullet \mathrm{mmol}[\mathrm{Cu}])-1)$ was similar to Gd-DTPA. The particulate r2 relaxivities were $\mathrm{r} 2=135,000 \pm 2900$ and ionic $\mathrm{r} 2$ relaxivities of $10.4 \pm 0.34$ $(\mathrm{s} \bullet \mathrm{mmol}[\mathrm{Cu}])-1$, respectively. NanoQ targeted to fibrin clot phantoms provided strong improvement in contrast-to-noise ratio $(\mathrm{CNR})(40 \mathrm{x} \mathrm{p}<0.05)$, while control clots (non-targeted and targeted no metal) had negligible contrast enhancement. NanoQ given intravenously as a bolus had a long half-life $(100 \mathrm{~min}, \mathrm{n}=3)$ determined by fitting two-compartment bi-exponential model fit (R2>0.99). ICP analysis of tissue copper 24 hours post injection revealed that approximately $90 \%$ of the metal was already eliminated from the animal.

\section{Conclusions}

Fibrin-specific NanoQ is a first high T1 relaxivity bivalent copper nanoparticluate MI agent that could afford sensitive noninvasive MR imaging of thrombus associated with ruptured plaques in high risk patients.

\section{Funding}

NIH.

\section{Author details}

'Medicine, Washington University Medical School, Saint Louis, MO, USA.

${ }^{2}$ Surgery, Saint Thomas', London, UK.

Published: 1 February 2012

(C) 2012 Pan et al; licensee BioMed Central Ltd. This is an open access article distributed under the terms of the Creative Commons 


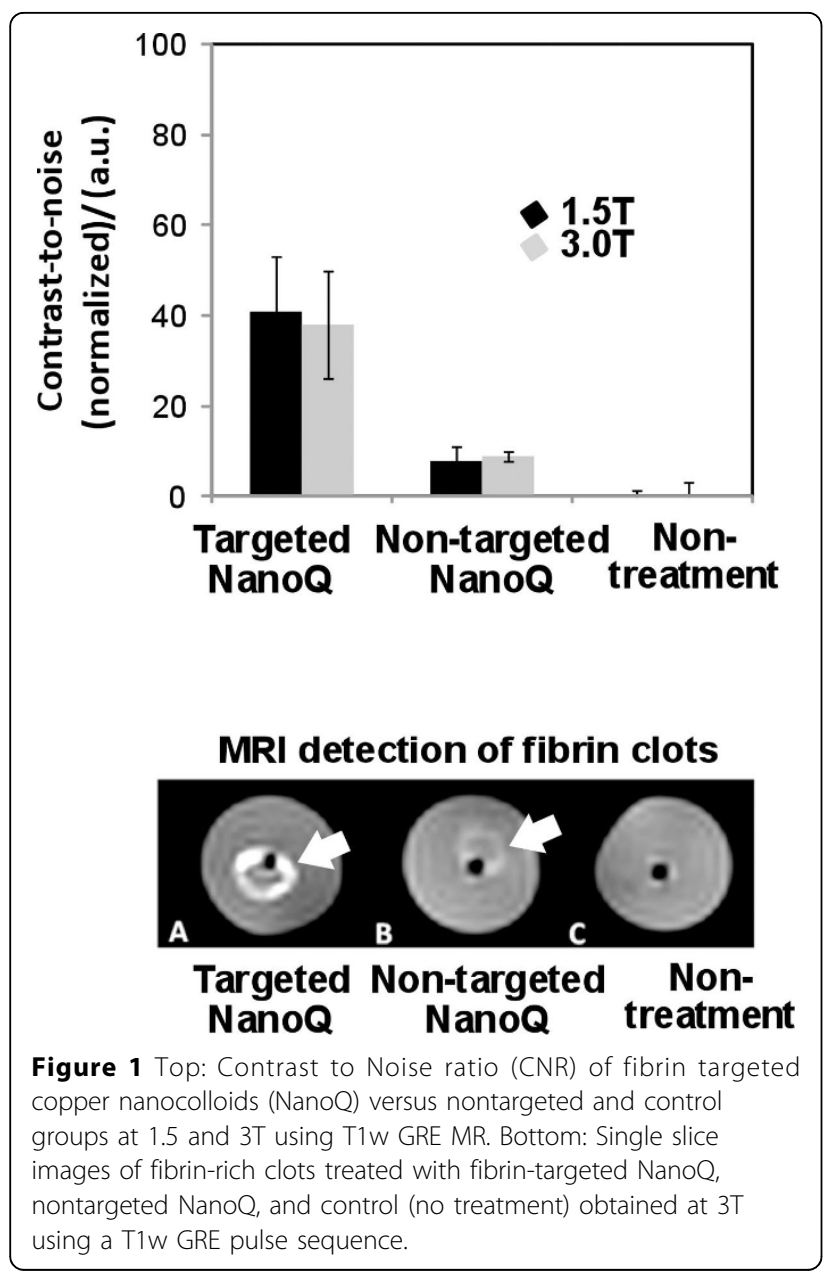

doi:10.1186/1532-429X-14-S1-042

Cite this article as: Pan et al:: Copper nanocolloids: a new thrombus molecular imaging approach to ruptured plaque. Journal of

Cardiovascular Magnetic Resonance 2012 14(Suppl 1):O42.
Submit your next manuscript to BioMed Central and take full advantage of:

- Convenient online submission

- Thorough peer review

- No space constraints or color figure charges

- Immediate publication on acceptance

- Inclusion in PubMed, CAS, Scopus and Google Scholar

- Research which is freely available for redistribution 